\title{
Przemiany przestrzeni w otoczeniu arterii komunikacyjnej na przykładzie ciągu ulicy Mogilskiej w Krakowie
}

\author{
Tomasz Bajwoluk
}

\begin{abstract}
Pracownia Odnowy Miast, Instytut Projektowania Miast i Regionów, Wydziat Architektury, Politechnika Krakowska, e-mail: t.bajwoluk@poczta.onet.pl
\end{abstract}

Streszczenie: Celem artykułu jest przedstawienie przemian przestrzeni w otoczeniu ciągu ulicy Mogilskiej w Krakowie. Arteria ta stanowi główny ciąg komunikacyjny łączący śródmieście Krakowa z Nową Hutą. Badania terenowe prowadzone przez autora obejmują ulicę Mogilską i Jana Pawła II. Od Ronda Mogilskiego, poprzez Rondo Czyżyńskie do Placu Centralnego im. Ronalda Reagana w Nowej Hucie. Otoczenie przedstawionej arterii komunikacyjnej zostało ukształtowane w różnych okresach, a jego struktura funkcjonalnoprzestrzenna stanowi interesujący przykład zróżnicowania formy oraz funkcji i jej wpływu na odbiór przestrzeni i charakter ulicy. Pomimo swojej kompozycyjnej roli w strukturze miasta łączącej dwie dzielnice Krakowa, dominująca jest przewaga czynnika komunikacji nad możliwościami stworzenia atrakcyjnej ulicy miejskiej, wyróżniającej się w przestrzeni miasta charakterem i jakością otoczenia. Przeprowadzone analizy użytkowania terenu, formy zabudowy oraz relacji kompozycyjnych wskazują na nie wykorzystanie potencjału tej arterii związanego przede wszystkim z jej unikalnym w skali miasta powiązaniu dwóch początkowo niezależnych zdefiniowanych zespołów urbanistycznych, historycznego Krakowa i Nowej Huty.

Trzy główne przestrzenie Rondo Mogilskie, Rondo Czyżyńskie i Plac Centralny w analizowanym ciągu ulic, pomimo podejmowanych działań inwestycyjnych stanowią dominujące w przestrzeni arterii węzły komunikacyjne z ograniczeniem ruchu pieszego. Nie sprzyja to integracji przestrzeni, a powstające nowe obiekty pomimo nowoczesnej formy tylko lokalnie wpływają na podniesienie atrakcyjności otoczenia i jakości tkanki miejskiej. Podjęty temat wskazuje na znaczenie kształtowania otoczenia miejskiej arterii komunikacyjnej dla podniesienia jej atrakcyjności i możliwości identyfikacji kompozycyjnej w przestrzeni. Istotnym elementem jest sama arteria jako ciąg komunikacyjny, jej szerokość, przebieg wraz z kształtem jej infrastruktury, ale także skala, forma i funkcja jej otoczenia. Racjonalne jego tworzenie w aspekcie kompozycyjnym i funkcjonalnym może budować w efekcie atrakcyjną przestrzeń miejską związaną z powiązaniami funkcjonalnymi, ale także ożywiać poszczególne fragmenty miasta oraz sprzyjać integracji otoczenia.

Słowa kluczowe: miasto, arteria komunikacyjna, struktura przestrzenna.

\section{Wprowadzenie}

Arterie komunikacyjne stanowią istotny element struktury funkcjonalno-przestrzennej miasta. Wiele $\mathrm{z}$ nich tworzy przestrzenie integrujące tkankę miejską. Arterie komunikacyjne mogą stanowić atrakcyjne przestrzenie publiczne będące rozpoznawalnymi symbolami miasta. Ich kształtowanie związane jest z procesem rozwoju ośrodków miejskich, a zagospodarowanie otoczenia stanowi o ich charakterze i atrakcyjności. Zachodzące 
relacje pomiędzy tkanką miejską, a komunikacją mają decydujący wpływ na formę przestrzeni, a także na jakość życia w mieście. Kształtowanie układów komunikacyjnych związane jest z przemianami struktury przestrzennej im towarzyszącej. Jest to również działanie wynikające $\mathrm{z}$ dostosowywania arterii komunikacyjnych do obowiązujących warunków technicznych, co powoduje zmiany w użytkowaniu przestrzeni, a także ma wpływ na odbiór i charakter ulicy. Istotnym czynnikiem są również lokalne uwarunkowania związane z istniejącą strukturą zabudowy jej podatnością na przemiany oraz możliwości zabudowy i zagospodarowania terenów sąsiadujących. Współczesne miasto w okresie dynamicznego rozwoju motoryzacji wymaga szczególnego podejścia do zagadnień kształtowania struktury funkcjonalno-przestrzennej towarzyszącej arterią komunikacyjnym [1]. Istotnym stają się wzajemne relacje pomiędzy komunikacja, a tkanką miejską. Dotyczy to zagadnień technicznych wynikających z obowiązujących przepisów, ale także funkcjonalnych i kompozycyjnych będących w zakresie działań podejmowanych przez architektów i urbanistów.

Celem artykułu jest przedstawienie przemian przestrzeni w otoczeniu ciągu ulicy Mogilskiej w Krakowie. Arteria ta stanowi główny ciąg komunikacyjny łączący śródmieście Krakowa z Nową Hutą. Badania terenowe prowadzone przez autora obejmują ulicę Mogilską i Jana Pawła II. Od Ronda Mogilskiego, poprzez Rondo Czyżyńskie do Placu Centralnego im. Ronalda Reagana w Nowej Hucie. Badania oparto o przeprowadzone własne analizy urbanistyczne struktury funkcjonalno-przestrzennej, dostępne materiały i opracowania planistyczne, wykonaną dokumentacje fotograficzną oraz analizę wybranych pozycji literatury związanych z podjętym tematem.

Wybór ulicy Mogilskiej w Krakowie stanowi charakterystyczny przykład przemian zachodzących w otoczeniu ważnej arterii komunikacyjnej miasta i ich wpływu na kształt, formę, charakter i odbiór przestrzeni będącej ulicą miejską, ale także przestrzenią publiczną łączącą ważne fragmenty miasta. Temat wydaje się istotny szczególnie obecnie z uwagi na dogęszczanie tkanki zabudowy w otoczeniu tej arterii, a także tendencję porządkowania i modernizacji miejskich ciągów komunikacyjnych.

\section{Charakterystyka ciągu ulicy Mogilskiej}

Ciąg ulicy Mogilskiej stanowi istotny element w strukturze funkcjonalno-przestrzennej Krakowa. Jest to arteria łącząca historyczne centrum miasta ze zbudowaną w latach 50-tych Nowa Hutą, początkowo nowym miastem, później dzielnicą Krakowa. Główny zespól urbanistyczny Nowej Huty wraz z Placem Centralnym został zrealizowany w latach 1949-55. Rozwój terytorialny dzielnicy nastąpił w późniejszych latach, wokół obecnie historycznej części od strony północnej i zachodniej powstały osiedla mieszkaniowe na terenach podkrakowskich wsi, w tym stopniowo tkanka zabudowy w otoczeniu analizowanej arterii [2]. Ciąg ulicy Mogilskiej i Jana Pawła II jest dwujezdniowy i towarzyszy mu komunikacja tramwajowa przebiegająca środkiem arterii. Struktura zabudowy w sąsiedztwie ulicy jest zróżnicowana pod względem wysokości, formy i funkcji Fot. 1. Początkowy zwarty charakter zabudowy mieszkaniowej od Ronda Mogilskiego, staje się coraz bardziej rozproszony w kierunku Nowej Huty. Zmieniająca się linia zabudowy i różna wysokość obiektów wprowadza chaos w przestrzeni ulicy i nie sprzyja tworzeniu spójnej przestrzeni. Pomiędzy ulicą Meissnera, a Rondem Czyżyńskim, arterii towarzyszy dawna podmiejska zabudowa obecnej dzielnicy Czyżyny, która z uwagi na uciążliwości ruchu kołowego ulega stopniowej degradacji. We fragmentach arteria graniczy z dawnymi terenami przemysłowymi zakładów farmaceutycznych, młynów i fabryki papierosów, oraz terenami zieleni urządzonej w tym 
Parkiem Lotników i kompleksem zieleni w sąsiedztwie Placu Centralnego. Struktura przestrzenna otoczenia ulicy Mogilskiej jest zróżnicowana pod względem funkcjonalnym. Charakterystycznym jest w zasadzie brak ciągów usługowych. Funkcje usługowe realizowane są jedynie w formie punktowej, co z ograniczoną szerokością ciągów pieszych nie sprzyja tworzeniu atrakcyjnych pierzei. Tereny pomiędzy Nową Hutą a Krakowem przez wiele lat były obszarem otwartym. Stopniowa ich zabudowa dotyczyła wybranych fragmentów, a istniejąca podmiejska struktura wzdłuż samej arterii nie podlegała istotnym przemianom. Traciła jednak na wartości z uwagi na uciążliwości związane z wzrastającym ruchem kołowym. W kompozycji Placu Centralnego powiązanie z Krakowem stanowiło raczej kontynuację trasy do Niepołomic i Sandomierza, a nie główny atrakcyjny kierunek założenia łączący obydwa zespoły urbanistyczne.

\section{Miejsca węzłowe}

Do miejsc węzłowych w ciągu ulicy Mogilskiej i Jana Pawła II możemy zaliczyć trzy główne przestrzenie, Rondo Mogilskie, Rondo Czyżyńskie i Plac Centralny stanowiące odmienne w charakterze przestrzenie publiczne Fot. 2. Istotne znaczenie dla odbioru i kompozycji ma także obszar przebudowanego skrzyżowania z ulicą Meissnera oraz Stelli Sawickiego będący ważną przestrzenią analizowanej arterii komunikacyjnej. Wskazane miejsca węzłowe łączy ich główna funkcja, są one przede wszystkim węzłami komunikacyjnymi generującymi ruch kołowy i pieszy. Wydaje się że dostosowanie ich do wymogów technicznych spowodowało dominację $\mathrm{w}$ przestrzeni i znaczne oddziaływanie na otoczenie. $Z$ uwagi na zastosowane rozwiązania techniczne arterie podporządkowano obsłudze ruchu kołowego i komunikacji miejskiej, ograniczając możliwość uatrakcyjnienia otoczenia. W obrębie miejsc węzłowych, arteria staje się barierą funkcjonalną i przestrzenną, a obszary sąsiadujące są ze sobą są mało zintegrowane. Rondo Mogilskie którego przebudowa nastąpiła w latach 2006-2008 stało się przestrzenią dwu poziomową [3]. Ruch pieszy, komunikacja zbiorowa oraz ścieżki rowerowe zostały zrealizowane w dolnej części, a ruch kołowy pozostał na dotychczasowym poziome terenu. Pomimo pionowej segregacji ruchu rozwiązanie to zdominowane jest przez ruch kołowy, a intensyfikacja zabudowy obszarów sąsiadujących dodatkowo sprzyja jego koncentracji. Charakter tkanki miejskiej sąsiadującej z Rondem Mogilskim jest zróżnicowany pod względem stylistycznym. Od strony zachodniej graniczy z XIX-wieczną zabudową klinik medycznych i Ogrodem Botanicznym UJ., od północy z osiedlem Oficerskim z zabudową rezydencjonalną zrealizowaną w 20-leciu międzywojennym. Część wschodnia w bezpośrednim sąsiedztwie Ronda Mogilskiego to zabudowa, użyteczności publicznej w tym biurowa, administracyjna i hotelowa. Kompozycyjnie Rondo Mogilskie stanowi przestrzeń łączącą ważne arterie miejskie. W kierunku północno-południowym to ulica Beliny Prażmowskiego oraz Powstania Warszawskiego, a w kierunku wschodnio-zachodnim to Mogilska i ulica Lubicz w stronę historycznego śródmieścia. Dominantami tej przestrzeni są budynek dawnego NOT., obecnie w trakcie przebudowy oraz nowy budynek biurowy w pierzei ulicy Powstania Warszawskiego. Obszar Ronda Mogilskiego jest ważny kompozycyjnie i funkcjonalnie ze względu na położenie pomiędzy dawnym Krakowem a Nową Hutą, wydaje się jednak niespójny pod względem formy zabudowy i zagospodarowania. Zróżnicowanie stylistyczne oraz wysokościowe poszczególnych obiektów, a także brak konsekwencji w przebiegu linii zabudowy nie sprzyja integracji przestrzeni, a jedynie jej urządzeniu. Dotyczy to obiektów od strony wschodniej i północnej. Rejon ten wymagał szczególnego podejścia do stworzenia całościowej koncepcji zagospodarowania terenu i konsekwentnej jej realizacji, nawet przez wiele lat z uwzględnieniem szerokiego spektrum 
lokalnych uwarunkowań. Plac Centralny im. Ronalda Reagana stanowi zasadniczy element kompozycyjny założenia urbanistycznego Nowej Huty. Brak jednak zakończenia układu urbanistycznego w części południowej, a także budowa w latach 80-tych Nowohuckiego Centrum Kultury (NCK) nie wpłynęła korzystnie na dokończenie tego zamierzenia urbanistycznego. Atrakcyjne trzy pierzeje Placu Centralnego z brakiem wizji zagospodarowania wnętrza placu i otwartej części południowej, a także koncentracja ruchu kołowego w znaczący sposób ogranicza potencjał i możliwości wykorzystania tego miejsca dla stworzenia przyjaznej mieszkańcom przestrzeni publicznej, a także symbolicznego zakończenia ciągu analizowanych arterii. Odrębną stylistycznie, ważną przestrzenią w ciągu ulicy Mogilskiej jest Rondo Czyżyńskie. Jego otoczenie zostało ukształtowane przez zespoły mieszkaniowe z lat 60-tych i 80-tych oraz zabudowę mieszkaniową jednorodzinną dawnych przedmieść Krakowa. Ze względu na dużą powierzchnie tego węzła komunikacyjnego ruch pieszy pomiędzy poszczególnymi częściami sprowadzono do przejść podziemnych. Pomimo podjętych prób modernizacji ich skala i długość nadal stanowi o negatywnym odbiorze tego miejsca. Struktura zabudowy w otoczeniu Ronda Czyżyńskiego jest zróżnicowana wysokościowo od parterowych domów istniejącej zabudowy po dziesięciopiętrowe budynki zespołów mieszkaniowych. Znaczne przemieszanie tych struktur, oraz skala przestrzeni pomiędzy nimi wpływa na brak spójności i powiązań kompozycyjnych. Rondo Czyżyńskie jest w pewnym stopniu przedpolem Nowej Huty, jednak ten czynnik w żaden sposób nie został wykorzystany przy kształtowaniu tkanki zabudowy $\mathrm{w}$ tej przestrzeni. Ważnymi funkcjonalnie i kompozycyjnie miejscami jest także skrzyżowanie ulicy Mogilskiej i Meissnera oraz ulicy Jana Pawła II i Stella Sawickiego Fot. 3,4. Pierwsze z nich umożliwiło dostęp do oddanej w roku 2015 hali widowiskowo-sportowej od strony południowej oraz jej ekspozycję w przestrzeni. Z uwagi na bliską odległość od zabudowy mieszkaniowej oraz rozbudowę samego węzła komunikacyjnego wzdłuż arterii, na tym fragmencie zastosowano ścianki akustyczne, których forma i gabaryty zdominowały odbiór sąsiadującej przestrzeni. Skrzyżowanie z analizowaną arterią ulicy Stella Sawickiego zostało zrealizowane jako dwupoziomowe. Daje to możliwość otwarć widokowych na sąsiadujące zespoły mieszkaniowe od północy, wprowadzając jednocześnie zmianę skali ulicy. Z uwagi na odległości pomiędzy sąsiadującą zabudową, arteria $\mathrm{w}$ tym rejonie ma jednak ograniczone związki z otaczająca strukturą. Charakter głównych miejsc węzłowych omawianej arterii jest zróżnicowany pod względem skali zabudowy jej formy oraz potencjału dla budowy atrakcyjnych przestrzeni integrujących tkankę zabudowy [4]. Pomimo przebudowy samej arterii nie osiągnięto efektu stworzenia reprezentacyjnej ulicy miejskiej, która dodatkowo wskazywałaby na jej unikalne znaczenie kompozycyjne w strukturze urbanistycznej Krakowa i Nowej Huty.

\section{Przemiany otoczenia - funkcjonalne i kompozycyjne}

Tkanka miejska w otoczeniu analizowanej arterii była kształtowana w różnych okresach. W zasadzie przemiany dotyczące arterii trwają także obecnie i wynikają z tendencji dogęszczania istniejącej struktury. $Z$ uwagi na lokalizacje Nowej Huty ranga ciągu ulicy Mogilskiej formalnie nie uległa zmianie. Początkowo arteria ta prowadziła przez obszary podmiejskich wsi, które z czasem uległy przemianom i stały się miejscem lokalizacji nowych inwestycji. W latach 60-70 tych powstała zabudowa mieszkaniowa w rejonie ulicy Grunwaldzkiej i zespoły osiedla Ugorek i Kolorowego. Lata 80-te to realizacja zabudowy w otoczeniu Ronda Czyżyńskiego oraz osiedla 2 Pułku Lotniczego. Wzdłuż arterii zlokalizowano również kompleksy dydaktyczne Politechniki Krakowskiej i AWF w latach 70-tych z planami rozbudowy w późniejszym okresie. Lata 90 -te to realizacja pojedynczych obiektów usługowych w rejonie 
ulicy Stella Sawickiego, które sukcesywnie uzupełniano funkcją handlową i biurową. Najbardziej stabilnym terenem pozostaje otoczenie arterii od Ronda Czyżyńskiego do Placu Centralnego w Nowej Hucie, z uwagi na uformowanie tego fragmentu w latach 60-tych i ograniczoną możliwość przekształcania struktury zabudowy mieszkaniowej tego obszaru. Wynika to z sąsiedztwa zakładów przemysłowych w tym rejonie, które zdominowały pierzeje południową arterii na znacznym fragmencie w kierunku Placu Centralnego. W przestrzeni arterii powstały także budynki wysokie. Zostały one zrealizowane jako pojedyncze obiekty w ramach istniejącej tkanki miejskiej. Należą do nich budynki biurowe zakładów farmaceutycznych, banku i policji pomiędzy Rondem Mogilskim, a ulicą Meissnera, zabudowa mieszkaniowa ulicy Ułanów i Ronda Czyżyńskiego, oraz realizowane obecnie biurowce w rejonie ulicy Stella-Sawickiego. Nie stanowią one jednak istotnych kompozycyjnie i architektonicznie zamknięć widokowych podnoszących jakość przestrzeni otoczenia ulicy, ich lokalizacja wynika bardziej z możliwości inwestycyjnych niż konsekwentnej lokalizacji pod względem kompozycyjnych zamknięć i lokalnych dominant [5].

\section{Uwarunkowania planistyczne}

Analizowany ciąg ulic Mogilska, Jana Pawła II w opracowanym w 2014 roku Studium Uwarunkowań i Kierunków Zagospodarowania Przestrzennego Krakowa (SUiKZPK) stanowi jeden z głównych ciągów miejskich w strukturze przestrzennej miasta [6]. Ten zapis wydaje się istotny i świadczy o dostrzeganiu przez projektantów znaczenia tej arterii w funkcjonowaniu i kompozycji tkanki miejskiej. Zapisy tego dokumentu planistycznego utrzymują dotychczasowy przebieg i formę zagospodarowania otoczenia. Jest to zabudowa mieszkaniowa wielorodzinna oraz usługi wbudowane lub wolnostojące. Przedstawiony ciąg ulic podlega także w części zapisom 11 obowiązujących Miejscowych Planów Zagospodarowania Przestrzennego (MPZP). Jest to obecnie MPZP Osiedle Oficerskie, Cystersów, Mogilska - Chałupnika, Ugorek - Fiołkowa, Ugorek Wschód, Lema - Staw Dąbski, Lema - Park Lotników, Stare Czyżyny, Marii Dąbrowskiej - Bieńczycka, Czyżyny - Łęg, Centrum Nowej Huty. Charakterystycznym jest, że w opracowanych planach ciąg ulicy Mogilskiej stanowi przestrzenną granicę zapisu zasad kształtowania zabudowy i zagospodarowania terenu. Różnią się one przyjętą powierzchnią oraz zasięgiem opracowania dla terenów sąsiadujących z analizowaną arterią, ale w przestrzeni ulicy każdy obejmuje jedną stronę. W bezpośrednim otoczeniu arterii obszary zachowują dotychczasową funkcję, sprzyjając w większości uzupełnieniu i dogęszczaniu zabudowy. Wydaje się że w praktyce realizacji zapisów planistycznych, pomimo założeń uporządkowania otoczenia trudno będzie uzyskać efekt spójności i atrakcyjności przestrzeni związanej z arterią. Oczywiście na końcowy rezultat ma znaczący wpływ istniejąca struktura funkcjonalno-przestrzenna i jej podatność na przekształcenia. Dotyczy to skali istniejących obiektów, ich formy architektonicznej i urbanistycznej, a także linii zabudowy. Nie bez znaczenia pozostaje także sposób zagospodarowania samej arterii jej szerokość, skala skrzyżowań i węzłów komunikacyjnych, oraz jakość ciągów pieszych i możliwość dostępności komunikacji miejskiej. Te czynniki w bezpośredni sposób oddziałują na kształt i odbiór przestrzeni w otoczeniu arterii komunikacyjnej, ale sposób ich tworzenia wynika również z precyzji zapisów i przestrzegania zasad zagospodarowania zawartych w opracowanych dokumentach planistycznych. Wydaje się jednak że obowiązujące MPZP dla tego obszaru nie wprowadzą zasadniczych zmian w charakterze arterii na analizowanym fragmencie. Lokalizowana punktowo zabudowa wysoka może jedynie zmienić proporcje otoczenia i akcentować lokalne dominanty nie stworzy jednak ciągłości i atrakcyjnych pierzei. 


\section{Podsumowanie i wnioski}

Przeprowadzone analizy użytkowania terenu, formy zabudowy oraz relacji kompozycyjnych wskazują na nie wykorzystanie potencjału tej arterii związanego przede wszystkim z jej unikalnym w skali miasta powiązaniu dwóch początkowo niezależnych zdefiniowanych zespołów urbanistycznych, historycznego Krakowa i Nowej Huty [7].

Trzy główne przestrzenie Rondo Mogilskie, Rondo Czyżyńskie i Plac Centralny w analizowanym ciągu ulic, pomimo podejmowanych działań inwestycyjnych stanowią dominujące w przestrzeni arterii węzły komunikacyjne $\mathrm{z}$ ograniczeniem ruchu pieszego, a nie atrakcyjne przestrzenie publiczne podnoszące jakość tkanki miejskiej. Nie sprzyja to integracji przestrzeni, a powstające nowe obiekty pomimo nowoczesnej formy tylko lokalnie wpływają na podniesienie jakości przestrzeni. Podjęty temat wskazuje na istotne znaczenie kształtowania otoczenia miejskiej arterii komunikacyjnej dla podniesienia jej atrakcyjności i możliwości identyfikacji kompozycyjnej w przestrzeni miasta. Ważnym elementem jest sama arteria jako ciąg komunikacyjny, jej szerokość, przebieg wraz z kształtem jej infrastruktury, ale także skala, forma i funkcja jej otoczenia. Racjonalne jego tworzenie w aspekcie kompozycyjnym i funkcjonalnym może budować w efekcie atrakcyjną przestrzeń miejską, a także ożywiać poszczególne fragmenty miasta oraz sprzyjać integracji otoczenia [8]. W przypadku ciągu ulicy Mogilskiej wydaje się że jej urbanistyczne znaczenie w skali miasta nie wpłynęło zasadniczo na kształtowanie jej otoczenia. Pomimo tworzenia struktury towarzyszącej arterii komunikacyjnej na przestrzeni wielu lat jej zasadniczy przebieg nie uległ zmianie. Świadczy to o dużej stabilności przestrzeni komunikacyjnych, ale także o braku możliwości przeprowadzenia gruntownych korekt poprawiających w efekcie odbiór i formę zabudowy. Zmieniające się uwarunkowania prowadziły do przemian jedynie w określonych obszarach. Dotyczyły one samej arterii, węzłów komunikacyjnych i jej infrastruktury nie powodując jednak podniesienia jej atrakcyjności. Same założenia ideowe zawarte w opracowaniach planistycznych bez mechanizmów wdrożenia tych zapisów pozostają jedynie koncepcjami nie znajdującymi odniesienia w realnej przestrzeni. Brak całościowej wizji kształtowania otoczenia arterii, nie sprzyja tworzeniu atrakcyjnej przestrzeni współczesnej ulicy miejskiej, ale także ogranicza możliwości jej przebudowy w przyszłości. Lokalizacja nowych obiektów pomimo atrakcyjnej formy architektonicznej, urbanistycznie w skali całej arterii prowadzi jedynie do punktowych zmian w odbiorze otoczenia, a nie pewnej konsekwencji w kształtowaniu całości tkanki miejskiej tworzącej spójną strukturę funkcjonalno-przestrzenną analizowanej ulicy [9]. Analiza przemian w otoczeniu wybranej arterii Krakowa pozwala na sformułowanie następujących wniosków ogólnych:

- w strukturze funkcjonalno-przestrzennej miasta jednym z istotniejszych obszarów są te fragmenty które towarzyszą głównym, ważnym kompozycyjnie arterią komunikacyjnym. Ich forma zagospodarowania, gabaryty i linia zabudowy w ich otoczeniu, funkcja oraz dostępność komunikacyjna obiektów, w tym przede wszystkim piesza, może konsekwentnie realizowana tworzyć atrakcyjną przestrzeń miejską;

- wybrane arterie komunikacyjne miasta winny podlegać na wyznaczonych istotnych odcinkach szczegółowym wytycznym urbanistyczno-architektonicznym określającym zasadnicze parametry kształtowania struktury funkcjonalno-przestrzennej; 
- istotnym elementem w kształtowaniu otoczenia i samej arterii są lokalne uwarunkowania wynikające ze specyficznych cech środowiska kulturowego i przyrodniczego. Właściwe nawiązanie do tych wartości może uzupełniać i indywidualizować wprowadzane w przestrzeni rozwiązania.

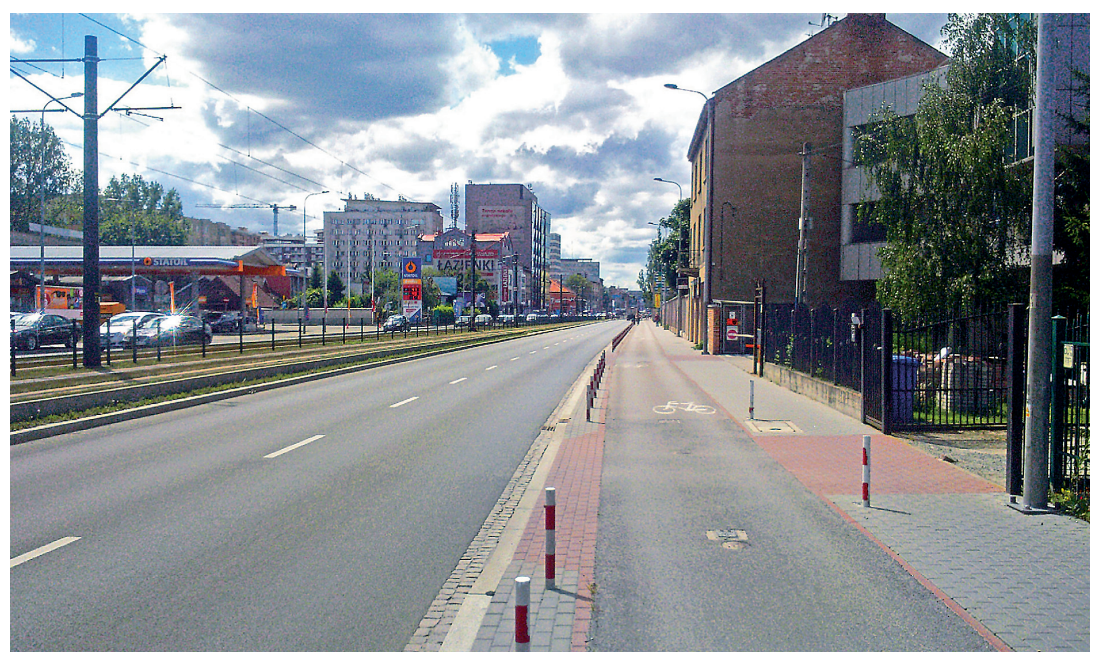

Fot. 1. Zróżnicowana stylistycznie i wysokościowo zabudowa ulicy Mogilskiej. Krótkie zwarte pierzeje bez usług i wąskie ciągi piesze, a także brak zieleni i możliwości zaparkowania nie sprzyjają atrakcyjności ulicy (autor. 2017)

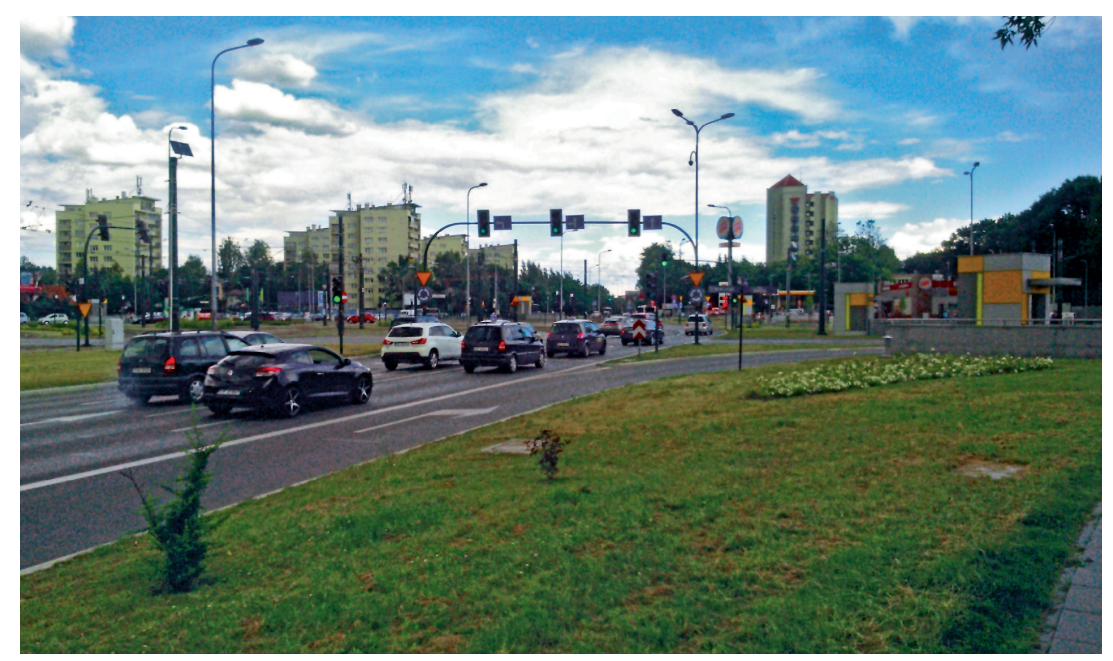

Fot. 2. Rondo Czyżyńskie - węzeł komunikacyjny, w otoczeniu zabudowa mieszkaniowa osiedla Kolorowego. Dominująca przestrzeń komunikacji nie integruje struktury towarzyszącej ulicy. (autor 2017) 


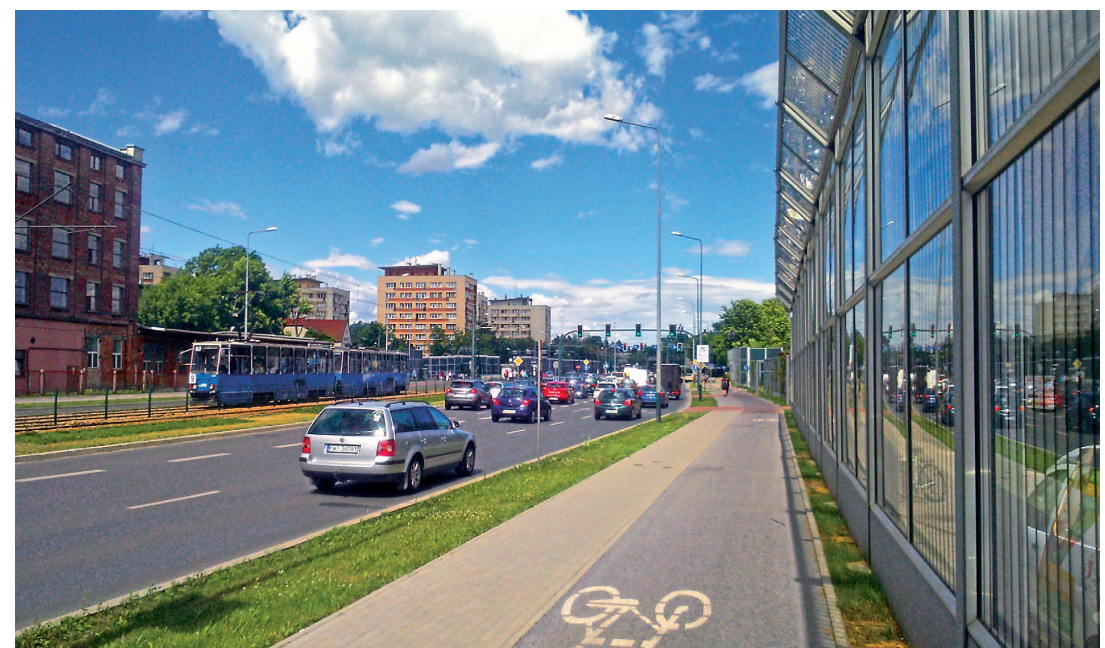

Fot. 3. Skrzyżowanie z ulicą Meissnera - ścianki akustyczne oddzielające zabudowę mieszkaniową. Zabezpieczenia akustyczne oraz wydzielona linia tramwajowa stają się dodatkowymi barierami funkcjonalnymi w przestrzeni ulicy. (autor 2017)

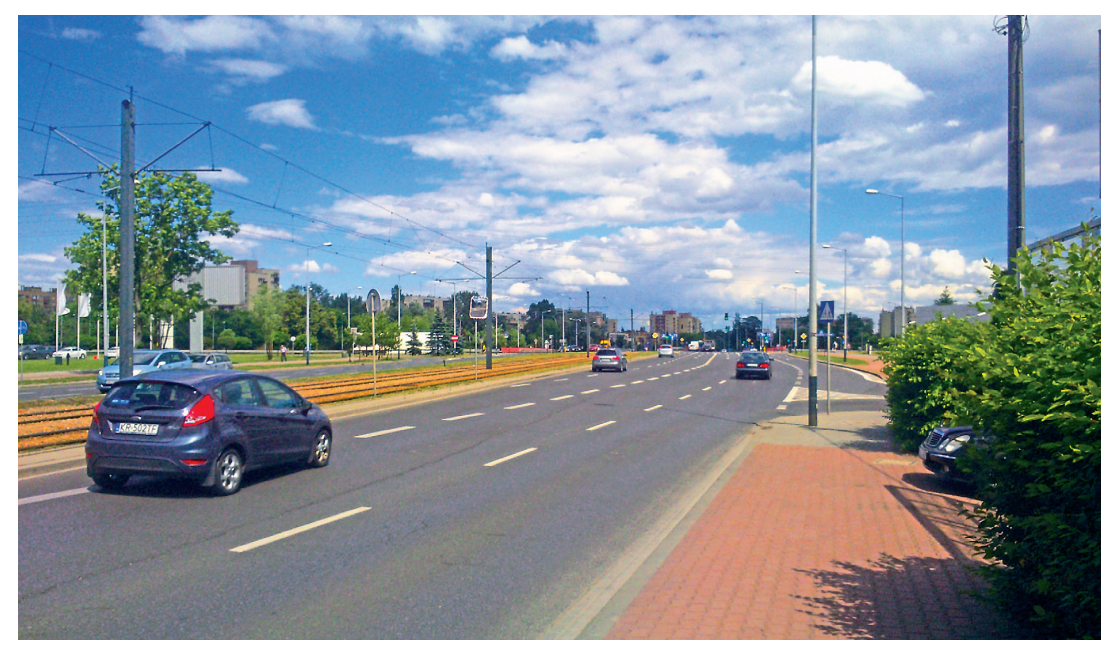

Fot. 4. Rozproszenie zabudowy i poszerzenie arterii w rejonie węzła komunikacyjnego i ulicy Stella Sawickiego, powoduje ograniczenie relacji pomiędzy sąsiadującą z arterią tkanką zabudowy. (autor 2017)

\section{Literatura:}

[1] Gawlikowski A. Ulica w strukturze miasta, wyd. Politechnika Warszawska , Warszawa 1992, 197-204.

[2] Mydel R. Terytorialny wzrost i ewolucja struktury przestrzennej miasta Krakowa w okresie 1946-1990, Folia Geographica series Geographica-Oeconomica XXVII-XXVIII (1996) 277-295. 
[3] Homiński B. Rondo Mogilskie w Krakowie - węzet drogowy czy plac w mieście, Czasopismo Techniczne 1-A 3(107) (2010) 355-361.

[4] Zuziak Z. O tożsamości urbanistyki, wyd. Politechnika Krakowska, Kraków 2008, s. 43-45.

[5] Ziobrowski Z. Urbanistyczne wymiary miast, wyd. IRM, Kraków 2012, s. 95-96.

[6] Studium Uwarunkowań i Kierunków Zagospodarowania Przestrzennego Miasta Krakowa, http://www.bip.krakow.pl/?id=48 z dnia 9.07.2014 ( dostęp 14.06.2017).

[7] Rykwert J. Pokusa miejsca, Przeszłość i przyszłość miast, Międzynarodowe Centrum Kultury, Kraków 2013 s. 248.

[8] Gzell S. Miastotwórcza rola transportu w teorii urbanistyki [w:] Czasopismo Techniczne 1-A 3(107) (2010) 16-17.

[9] Chmielewski J.M. Teoria urbanistyki w projektowaniu i planowaniu miast, Oficyna Wydawnicza Politechniki Warszawskiej, Warszawa 2005, s. 45-50.

\title{
Spatial transformations in the surroundings of a transportation artery. The case of Mogilska street in Kraków
}

\author{
Tomasz Bajwoluk
}

Urban Renewal Laboratory, Institute of City and Regional Planning, Faculty of Architecture, Cracow University of Technology, e-mail: t.bajwoluk@poczta.onet.pl

\begin{abstract}
The aim of the article is to present transformations of space in the surroundings of Mogilska street in Kraków. The artery is a main transportation route connecting central Kraków with Nowa Huta. The field research conducted by the author cover Mogilska and Jana Pawła II streets, from Mogilskie roundabout, to Czyżyńskie roundabout and further on up to Ronald Reagan Centralny Square in Nowa Huta. The surroundings of the presented transportation artery were created in different periods of time and their functional and spatial structure is an interesting example of form and function diversity and its influence on how the space and character of the street is perceived. Although the street plays an important compositional role in the structure of the city as it connects two districts of Kraków, the dominant transportation function prevents it from becoming an attractive city street standing out in the city space due to the character and quality of its surroundings. The analysis of land use, development form and compositional relations points out to the potential of this artery stemming primarily from its role - unique in the scale of the city - as a connection between two initially independent urban organisms: historic Kraków and Nowa Huta, which potential remains largely untapped.

The three major spaces: Mogilskie roundabout, Czyżyńskie roundabout and Centralny Square still remain dominant transportation hubs in the space of the artery with limited pedestrian traffic, in spite of all the development effort to prevent this. The situation does not promote integration of space, and the newly erected facilities, despite their modern form, are able to improve the attraction of the surroundings and urban fabric quality only locally. The issue in question highlights the significance of designing the surroundings of an urban transportation artery for the improvement of its attraction and compositional identification
\end{abstract}


in a space. An important component is the artery itself as a transportation route, its width, course and infrastructure, but also the scale, form and function of its surroundings. Rational development of such surroundings in the compositional and functional aspect may, as a result, produce an attractive and functionally interconnected urban space, as well as invigorate individual parts of the city and promote integration of the surrounding areas.

Keywords: city, transportation artery, spatial structure. 